\title{
Idiopatinių intersticinių pneumonijų
}

\section{naujovès}

\author{
Greta Musteikienè \\ LSMU MA Pulmonologijos ir imunologijos klinika
}

Reikšminiai žodžiai: intersticinės plaučių ligos, idiopatinė intersticinė pneumonija, idiopatinė plaučių fibrozė.

Santrauka. Idiopatinės intersticinės pneumonijos - nežinomų priežasčių sukeltos ligos, priklausančios intersticinių plaučių ligų grupei. Šiomis ligomis sergantys pacientai į gydytoją dažniausiai kreipiasi dèl dusulio ar sauso kosulio. Diagnozė kartais nustatoma remiantis didelès skiriamosios gebos kompiuterinės tomografijos duomenimis, bet dažniausiai tiksliai diagnozei patvirtinti reikalinga chirurginè plaučių audinio biopsija. Klinikinèje praktikoje idiopatinės intersticinės pneumonijos diagnostika yra sudètinga, rekomenduojama, kad diagnozė būtų nustatyta bendru pulmonologo, radiologo ir patologo sprendimu, jivertinus atliktų tyrimų duomenis. Siekiant palengvinti šių ligų diagnozavimo ir gydymo sampratą išleista mokomoji knyga "Idiopatinės intersticinės pneumonijos".

Intersticinès plaučių ligos - gana paslaptinga ligu grupé, apimanti daugiau kaip du šimtus nevėžinių, neinfekcinių, ūminių ar lètinių ligų, pažeidžiančių intersticiní plaučių audinị. Šios ligos retos, sudaro apie 15 proc. visų plaučių ligų. Sergamumas vyrų - 80,9 iš 100 tūkst., moterų - 67,2 iš 100 tūkst. Dalis jų sunkios, greitai progresuojančios, reikalingos specifinio gydymo, todèl jas būtina kuo skubiau diagnozuoti.

Dažniausiai nustatomos intersticinių plaučių ligų priežastys yra aplinkos veiksniai (ypač organinès ir neorganinès kilmès dulkès), apšvita, vaistai, jos gali išsivystyti ir sergant daugeliu sisteminių jungiamojo audinio ligų. Šiuo metu skiriamos šios intersticinių plaučių ligų grupès: sukeltos sisteminių jungiamojo audinio ligų; jatrogeninès; profesinès; imuninès; idiopatinès intersticinès pneumonijos; kitos.

Intersticinèms plaučių ligoms priskiriama ir nedidelè, heterogeniška, nežinomų priežasčių sukelta intersticinių

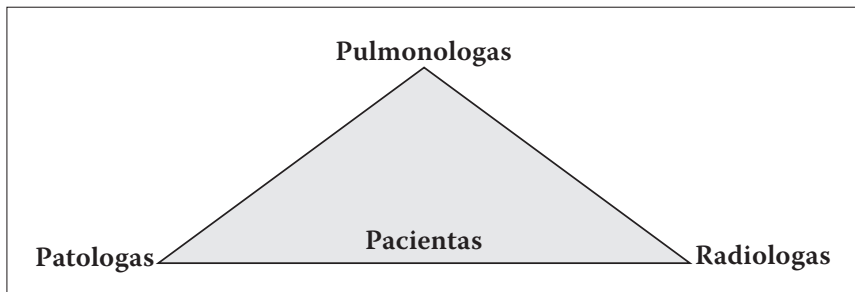

plaučių ligų grupè - idiopatinès intersticinès pneumonijos. Sergant idiopatinėmis intersticinèmis pneumonijomis, iki šiol nežinomas veiksnys sukelia plaučių parenchimos uždegimą, o vèliau ir fibrozę. Remiantis 2013 metų klasifikacija skiriamos 6 pagrindinès (idiopatinè plaučių fibrozé; idiopatinè nespecifinè intersticinė pneumonija; respiracinis bronchiolitas su intersticine plaučiú liga; deskvamacinè intersticinè pneumonija; kriptogeninė organizuojamoji pneumonija; ūminè intersticinè pneumonija) ir 2 retos (idiopatinè limfoidinè intersticinè pneumonija; idiopatinè pleuroparenchiminé fibroelastozè) idiopatinès intersticinès pneumonijos. Dažniausia jų - idiopatinė plaučių fibrozè, sudaranti daugiau kaip pusę iš visų šių ligų atvejų. Remiantis ịvairiais šaltiniais, Europos Sąjungoje yra apie 80-100 tūkst. pacientų, sergančiu idiopatine plaučiuc fibroze. Sergamumas kitomis idiopatinemis intersticinėmis pneumonijomis nèra tiksliai žinomas.

Dažniausiai sergantieji intersticinėmis plaučių ligomis ì gydytoją pulmonologą kreipiasi nustačius difuzinių pokyčių krūtinès ląstos rentgenogramoje; atsiradus ir nuolat stiprejjant dusuliui, sausam kosuliui; kai sergant sistemine jungiamojo audinio liga išryškèja plaučių pažeidimo simptomai; įtarus profesinę ligą.

Tiriant pacientus dažniausiai nustatomas dujų difuzijos ir restrikcinio tipo ventiliacinès plaučių funkcijos 
sutrikimas. Jeigu atsiranda kvejpavimo nepakankamumas, jis būna hipokseminis hipokapninis. Periferinio kraujo tyrimų rezultatai dažniausiai nespecifiniai, tačiau, įtariant sisteminès jungiamojo audinio ligos sukeltą plaučių pažeidimą, tiriami sisteminių ligų žymenys. Bronchoalveolinio lavažo tyrimas nèra labai naudingas intersticinių plaučių ligų diagnostikai, tačiau gali suteikti papildomos informacijos, kai jo rezultatai derinami su kitų tyrimų duomenimis.

Krūtinès ląstos rentgenograma - tik atrankinis tyrimo metodas. Didelès skiriamosios gebos kompiuterinè tomografija yra radiologinès intersticinių plaučių ligų diagnostikos aukso standartas. Šio tyrimo jautrumas diagnozuojant jas yra 95 proc. o specifiškumas - beveik 100 proc. Remiantis šio tyrimo vaizdais, galima parinkti ir plaučių audinio biopsijos vietą, jei ji yra reikalinga.

Jei po visų atliktuc klinikinių, laboratorinių ir radiologinių tyrimu intersticinès plaučių ligos diagnozè nepaaiškejja, reikia atlikti plaučių audinio biopsiją. Mažiausiai invazinė yra transbronchinè biopsija, tačiau ji tinkama tik tuo atveju, jei histologiškai ištirti bei diagnozei nustatyti pakanka nedidelio plaučių audinio fragmento (pvz., diagnozuojant sarkoidozę, eozinofilinę pneumoniją), ir beveik jokiu atveju netinka, kai ịtariama idiopatinè intersticinè pneumonija. Dažnai intersticinių plaučių ligų požymiai nesitelkia vienoje vietoje, o randami išsibarstę plaučiuc audinyje, todèl histologinei diagnostikai naudojami chirurginiai metodai (vaizdo torakoskopinè arba atviroji plaučių audinio biopsija, imama torakotomijos metu), kurių metu gaunamas didesnis medžiagos kiekis histologiniam tyrimui.

Pagrindiniai histologiniai požymiai, sergant intersticinemis plaučių ligomis, yra fibroblastų proliferacija ir kolageno depozicija, tačiau galimų histologinių požymių yra mažiau nei pačių ligų. Kai kurie požymiai yra patognominiai ir būdingi tik tam tikrai ligai, tačiau daugiau tokių, kurie gali būti randami esant ịvairioms intersticinėms plaučių ligoms. Reikalinga paminèti, kad histologinis tyrimas mažai naudingas, jei intersticinė liga paskutinès stadijos ir yra ryški fibrozè (bus rasti tik nespecifiniai pokyčiai) arba po gydymo, nes patys vartojami vaistai gali sukelti plaučių pažeidimą.

Intersticinès plaučių ligos negali būti diagnozuojamos remiantis vien tik biopsija. Diagnozuojant šias ligas, būtinas pulmonologo, radiologo ir patologo bendradarbiavimas. Pulmonologas gali nurodyti, kad yra intersticinès plaučių ligos požymių, kurie leistų galvoti apie tam tikros diagnozès tikimybę. Radiologas gali susiaurinti tikimybę atsižvelgdamas $\mathfrak{i}$ didelès skiriamosios gebos kompiuterinès tomografijos duomenis. Kadangi histologiniai pokyčiai yra santykinai mažo specifiškumo, patologas turi turèti klinikinès informacijos ir radiologinių tyrimų duomenis. Ivertinę visus turimus duomenis, šie specialistai turètų prieiti prie bendros išvados.
Dauguma intersticinių plaučių ligų gydomos citostatikais ir gliukokortikoidais. Pacientams taip pat rekomenduojama reabilitacija, kuri gerintų plaučių funkciją, esant kvėpavimo nepakankamumui - gydymas deguonimi, kai kuriems - nuolatinè ambulatorinè neinvazinè arba net invazinė plaučių ventiliacija. Plaučių pažeidimui progresuojant, sprendžiama, ar reikalinga plaučiuc transplantacija.

Ligoniai, sergantys idiopatinėmis intersticinèmis pneumonijomis, turètų būti gydomi universitetų ligoninėse. Empirinis gydymas neturètų būti skiriamas, jei nèra tikslios diagnozės, nes vaistai (gliukokortokoidai, imunosupresiniai) sukelia daug šalutinių reiškinių ir gali būti neveiksmingi gydant kai kurias intersticines plaučių ligas. Pavyzdžiui, idiopatinè plaučių fibrozè laikoma atsparia gydymui standartiniais vaistais. Šiai ligai gydyti gali būti skiriami specifiniai vaistai (pirfenidonas, nintedanibas).

Jau praejjo dvidešimt metú nuo tada, kai Lietuvoje buvo išleistas atskiras leidinys gydytojams praktikams, kuriame išsamiai aprašytos intersticinès plaučių ligos, o atskiros knygos apie idiopatines intersticines pneumonijas išleista nebuvo iki šiol. Pastaruoju metu šioje srityje atsirado nemažų diagnostikos ir gydymo pokyčių. Dèl šių priežasčių LSMU MA pulmonologai kartu su radiologais ir patologais išleido mokomąją knygą „Idiopatinès intersticinès pneumonijos“. Knyga parašyta norint palengvinti šių ligų diagnozavimo ir gydymo sampratą, pateiktos naujausios tarptautinès diagnostikos ir gydymo rekomendacijos. Joje trumpai apžvelgtos ir kitos intersticinès plaučių ligos, pateikta sukauptų radiologinių ir histologinių duomenų.

Autoriai tikisi, kad leidinys bus vertingas ne tik medicinos studentams ir rezidentams, bet ir jau dirbantiems pulmonologams, radiologams, patologams, vidaus ligų, šeimos ir kitų specialybių gydytojams.

\section{DEVELOPMENTS IN IDIOPATHIC INTERSTITIAL PNEUMONIAS}

\section{GRETA MUSTEIKIENE \\ DEPARTMENT OF PULMONOLOGY AND IMMUNOLOGY ACADEMY OF MEDICINE LITHUANIAN UNIVERSITY OF HEALTH SCIENCES}

Keywords:interstitial lung diseases; idiopathic interstitial pneumonias; idiopathic pulmonary fibrosis.

Summary. Idiopathic interstitial pneumonias are diseases of unknown cause and belong to the group of interstitial lung diseases. Patients suffering from these diseases usually complain of dyspnoea or dry cough. The diagnosis of idiopathic interstitial pneumonia is sometimes based on high-resolution computed tomography, but generally it requires a surgical lung biopsy. In clinical practice, diagnosis of these diseases is difficult, and it is recommended that the diagnosis is made by a common decision of pulmonologist, radiologist and pathologist. In order to facilitate the diagnosis and treatment of these diseases, the teaching book "Idiopathic interstitial pneumonias" was published. 